\title{
Perilaku Keagamaan Santri Lanjut Usia(LANSIA) di Pondok Pesantren Sepuh Masjid Agung Payaman Magelang
}

\author{
Imam Machali \\ Fakultas Ilmu Tarbiyah dan Keguruan UIN Sunan Kalijaga Yogyakarta \\ Email: imam.machali@uin-suka.ac.id \\ Mangun Budiyanto \\ Fakultas Ilmu Tarbiyah dan Keguruan UIN Sunan Kalijaga Yogyakarta \\ Email: mangunbudiyanto@yahoo.com
}

\begin{abstract}
This article aims to study the religious behavior of elderly studentsin Islamic boarding school of Sepuh Payaman Magelang. analysisinthisstudyisthroughthe fivedimensions; religious belief (ideological), religious practice (ritualistic), religious knowledge (intellectual), religious appreciation (experiential), and experience religion (consequential). The results of this study showed that the ideological dimension embodied in the belief of the pillars of faith in the form of full submission to God as the One single, unified set of all creatures on lafadz tahlil "laa ilaha illa Allah". Second, ritualistic dimension embodied in the practice of religious activities both mahdloh and ghairu mahdlah. Third, Intellectual manifests in learning activities and assessment of students using the book of al-ibriz li Ma'rifah Tafsir al-Qur'an al-Aziz by KH. Bisri Mustafa. The method of the study is "eavesdrop" or listening carefully. Various activities undertaken by the elderly students is serveas a provisioninthe hereafter. Fourth, experiential dimensions embodied in belief and consciousness that hereafter is is the goal of this life. Fifth, consequential dimension manifests in elderly students that all daily activities are always supervised by God and recorded by the angels.
\end{abstract}

Keywords:ReligiousBehavior, elderly students, Islamic Boarding School Sepuh

Artikel ini bertujuan untuk mengetahui perilaku keagmaan santri Lansia di Pondok Pesantren Sepuh Masjid Agung Payaman Magelang yang dilihat dalam lima dimensi yaitu dimensi keyakinan agama (ideologis), praktek keagamaan (ritualistik), pengetahuan agama (intlektual), penghayatan keagamaan (eksperensial), dan pengalaman agama (konsekuensial). Hasil penelitian menunjukkan bahwa pertama dimensi ideologis mewujud dalam keyakinan terhadap rukun iman berupa kepasrahan penuh terhadap Allah sebagai dzat tunggal yang mengatur semua makhluk yang manunggal pada lafadz tahlil "laa ilaaha illallah". Kedua, dimensi ritualistik mewujud dalam praktik kegiatan keagamaan baik mahdloh maupun ghairu mahdlah. Ketiga, Intelektual mewujud dalam aktifitas pembelajaran dan kajian santri dengan menggunakan kitab al-ibriz li Ma'rifah Tafsir al-Quran al-Aziz karya KH. Bisri Mustofa. Metode yang digunakan dalam pembelajaran dengan metode "nguping" yaitu metode denganmendengarkan dengan seksama. Berbagai aktifitas yang dilakukan oleh para santri lansia dalam keykinannya dijadikan sebagai bekal di akhirat. Keempat, dimensi eksperensial mewujud dalam Keyakinan dan kesadaran bahwa sangat sadar bahwa kehidupan akhiratlah yang menjadi tujuan. Kelima, dimensi konsekuensial mewujud dalam keyakinan para santri lansia bahwa segala aktifitasnya sehari-hari selalu diawasi oleh Allah dan dicatat oleh malaikat.

Kata Kunci: Perilaku Keagamaan, Lanjut Usia, Pesantren Sepuh 


\section{Pendahuluan}

Umumnya pondok pesantren dihuni oleh para santri yang berusia remaja awal hingga dewasa awal baik lai-laki maupun perempuan. Mereka belajar dan mendapatkan pendidikan berdasarkan kurikulum yang telah dirumuskan oleh pesantren, baik formal maupun non formal.

Berbeda dengan pondok pesantren pada umumnya, pondok pesantren Sepuh Masjid Agung Payaman Magelangdihuni oleh para santri Lanjut Usia (LANSIA). Pondok pesantren ini berdiri pada bulan maret tahun1952yang dilatarbelakangi oleh banyaknya santri sepuh (lanjut usia)yang menginap di masjid untuk keperluan mengikuti pengajian "Selasan"(pengajian rutin yang diadakan setiap hari Selasa), oleh karena dikhawatirkan mengganggu jama'ah lain di masjid Agung akhirnya didirikanlah pondok pesantren tersebut. Selain hal tersebut, gagasan pendirian pondok pesantren sepuh Masjid Agung Payaman Magelang ini adalah karena banyaknya santri sepuh (lanjut usia) yang mempunyai keinginan kuat belajar ilmu agama. Mereka menyadiri pada waktu anak-anak atau remaja dahulu tidak mempunyai banyak kesempatan untuk belajar agama karena kesibukan, kondisi social politik (penjajahan) yang tidak memungkinkan belajar, dan berbagai alasan lainnya. Sehingga pada usia tua ini mereka sangat merindukan pemahaman, dan ajaran agama. Sampai saat ini, Pondok Pesantren Masjid Agung Payaman Magelang terus menampung santri lanjut usia yang ingin belajar dan memperdalam ilmu dan ajaran agama Islam.

Program kegiatan yang dilakukan di pondok pesantrenSepuh Masjid Agung Payaman Magelangmeliputi pembelajaran baca tulis al Qur'an, pelatihan shalat, puasa, dzikir, bacaanbacaandoa sehari-hari,serta pengetahuan-pengetahuan agama lain, yang di bimbing oleh para ustadz dan kyai.Secara umum kegiatan pembelajaran di Pondok Pesantren Sepuh Masjid Agung Payaman Magelanglebih diarahkan pada proses penghayatan dan pengamalan ajaran-ajaran agama Islam agar para santri Lansia semakin siap dan tenang dalam menghadapi hari tuanya. Sehingga santri Lansia mampu mengaktualisasikan dirinya sebagai manusia seutuhnya.

Beberapa hal yang menarik dari pondok pesantren ini adalah pertama, pondok pesantren Sepuh Masjid Agung Payaman Magelangmerupakan pesantren langka dan unik yang ada di Indonesia yang menampung santri Lansia. Kedua, para Lansia sering diidentikan dengan seorang yang berusia lanjut dengan sisa-sisa usia yang dimilikinya dihabiskan untuk menghadapi kematian menghadap Sang Khalik. Ketiga,para Lansia diusianya yang tua sering dilihat sebagai kaum yang mempunyai perilaku keagamaan tertentu, sehingga pada kondisikondisi tertentu Lansia rajin dan bersemangat mengikuti kegiatan-kegiatan keagamaan termasuk bergabung di pondok pesantren. Beberapa hal tersebut menjadikan pembelajaran penting ke depan untuk membangun pola pikir tentang Lansia. Artikel ini membahas tentang perilaku keagamaan santri lanjut usia (Lansia) di pondok pesantren Sepuh Masjid Agung Payaman Magelang.

\section{Keagamaan Pada Usia Lanjut}

Lanjut usia ialah periode penutup dalam rentang hidup seseorang, yaitu suatu periode dimana seseorang telah "beranjak jauh" dari periode terdahulu yang lebih menyenangkan, atau beranjak dari yang penuh dengan manfaat. Menua (menjadi tua) adalah suatu proses menghilangnya secara perlahan-lahan kemampuan jaringan untuk memperbaiki diri atau mengganti dan mempertahankan fungsi-fungsi normalnya sehingga tidak dapat bertahan terhadap infeksi dan memperbaiki kerusakan yang diderita. (Bandiyah, 2009: 13)

Suardiman (2011: 1) menjelaskan bahwa menjadi tua (aging)merupakan proses perubahan biologis secara terus-menerus yang dialami oleh manusia pada semua tingkat umur dan waktu, sedangkan usia lanjut (old age) adalah istilah untuk tahap akhir dari proses penuaan tersebut.Adapun di usia lanjut yaitu setelah usia di atas 65 tahun manusia akan menghadapi sejumlah permasalahan. Permasalahan itu ialah penurunan fisik hingga terjadinya gangguan 
pada fisik. Pada usia ini mereka cenderung menyukai kegiatan keagamaan sebagai bentuk pemanfaatan masa akhir yang dimilikinya. ( Hurlock. 2002: 379).

Periode selama usia lanjut terjadi perubahan-perubahan atau terjadinya masa kemunduran yang sesuai dengan hukum kodrat manusia yang pada umumnya dikenal dengan istilah "penuaan". Kemunduran ini merupakan suatu perubahan pada sel-sel tubuh dan bukan karena penyakit, akan tetapi karena proses penuaan.

Pada masa lanjut usia, kesadaran akan keberagamaan semakin meningkat. Robert $\mathrm{H}$ Thouless dalam penelitiannya menjelaskan bahwa pengakuan terhadap realitas kehidupan akhirat baru muncul sampai 100 persen setelah usia 60 tahun keatas.Faktor yang juga ikut menentukan kesadaran terhadap sikap keagamaan Lansia adalah semakin mendekatnya masa kematian. Dalam pandangan William James menyatakan bahwa keagamaan pada usia lanjut sangat luar biasa tampak ketika kehidupan seksual sudah berakhir. Packard, Bossard, dan Boll menjelaskan bahwa besarnya minat para lansia terhadap agama lebih didorong oleh alasanalasan lain dibandingkan dengan alasan keagamaan itu sendiri. Pada kenyataannya, kebebasan yang diperoleh dari pekerjaan rumah dan tanggung jawab ke-orangtua-an khususnya bagi lansia wanita membuat aktifitas mereka dalam kegiatan keagamaan dan kegiatan sosial lainnya menjadi meningkat.(Mappiare,1983: 219-220).

Agama juga dipercayai dapat melepaskan kecemasan seseorang tentang sebuah kematian dan kehidupan setelahnya. Perasaan akan takut pada kematian cenderung menyertai kepercayaan terhadap agama. Kehadiran dan partisipasi para lansia pada lembaga dan kegiatan keagamaan merupakan bukti bagi penyesuaian kehidupan keagamaan mereka. Di dalam al-Quran (alMukmin: 67) digambarkan siklus kehidupan manusia yang dimulai dari tanah kemudian setetes mani, ditiupkannya ruh hingga kematian.

"Dia-lah yang menciptakan kamu dari tanah kemudian dari setetes mani, sesudah itu dari segumpal darah, kemudian dilahirkannya kamu sebagai seorang anak, kemudian (kamu dibiarkan hidup) supaya kamu sampai kepada masa (dewasa), kemudian (dibiarkan kamu hidup lagi) sampai tua, di antara kamu ada yang diwafatkan sebelum itu. (Kami perbuat demikian) supaya kamu sampai kepada ajal yang ditentukan dan supaya kamu memahami(nya)”.

Seorang yang masuk dalam sebuah kelompok keagamaan akan mendapatkan sebuah dorongan untuk lebih giat dalam ibadah dan sebuah rasa aman.Sedangkan orang yang tidak mengikuti sebuah kelompok keagamaan kurang mendapatkan dorongan sosial semacam itu. Beberapa pengaruh umum dari perubahan keagamaan pada usia lanjut adalah 1) toleransi keagamaan, yaitu meningkatnya usia berpengaruh dalam keterbukaan dalam mengikuti ajaranajaran agama serta lebih rajin dalam mengikuti kegiatan-kegiatan keagamaan. 2) keyakinan keagamaan, yaitu keyakinan yang dimiliki oleh para lansia semakin meningkat seiring bertambahnya usia serta partisipasi dalam sebuah kegiatan keagamaan. Dan 3) ibadat keagamaan, partisipasi dalam kegiatan-kegiatan keagamaan dari para lansia meningkat seiring dengan berkurangnya tanggungjawab rumah tangga. Aktif dalam kegiatan keagamaan di tempattempat ibadah dapat meningkatkan hubungan sosial diantara satu dengan yang lainnya.

Berdasarkan perubahan-perubahan keagamaan yang terjadi pada para lansia, selanjutnya mereka mempunyai beberapa ciri-ciri keberagamaan sebagaimana berikut: 1) kehidupan keberagamaan lansia mencapai tingkat pemantapan; 2) kecenderungan terhadap ajaran/dogma agama semakin meningkat; 3) kepercayaan mengenai kehidupan akhirat menjadi semakin meningkat; 4) sikap keagamaan yang cenderung mengarah pada kebutuhan saling cinta antar sesama, serta sifat-sifat luhur; 5) timbulnya kesadaran akan datangnya kematian seiring dengan bertambahnya usia; 6) kesadaran akan kematian berdampak pada peningkatan sikap keagamaan dan kepercayaan terhadap kehidupan akhirat. (Jalaluddin, 2007: 112-113). 
Kepercayaan umum yang mengatakan "akan adanya kehidupan yang akan datang" terdapat dibanyak kebudayaan di dunia ini, dari kebudayaan yang primitif hingga kebudayaan barat yang sudah maju. Kepercayaan tersebut membuat kematian bukanlah sebagai akhir dari segalanya tetapi kematian merupakan sebuah perubahan hidup seseorang. (Leahay, 1996: 8)

Keagamaan pada usia lanjut juga tidak terlepas dari arti penting puasa bagi manusia. Puasa tidak hanya baik dari sudut pandang agama, tetapi juga terbukti di dunia medis bahwa puasa membawa dampak yang baik bagi kesehatan manusia. Puasa mengendalikan nafsu makan seseorang, artinya seseorang tidak dapat makan sewaktu-waktu. Karena para lansia pada umumnya telah mengalami penurunan kekuatan fisik maka makanan yang dimakan juga perlu perhatian tersendiri. Menjaga kesehatan para lansia dengan pola dan menu makan yang sehat dan sesuai dapat menjaga para lansia untuk tetap sehat. Apabila makanan yang dikonsumsi tidak disesuaikan dengan perubahan fisik para lansia, maka dikhawatirkan akan menimbulkan penyakit. (Suardiman, 2011: 155-156).

Keberagamaan atau religiousitas (religiusity)seseorang — termasuk lansia-dapat dilihat melalui lima dimensi yaitu dimensi keyakinan agama (ideologis), dimensi praktek keagamaan (ritualistik), dimensi pengetahuan agama (intlektual), dimensi penghayatan keagamaan (eksperensial), dimensi pengakaman agama (konsekuensial). Keberagamaan bermakna "beragama atau beriman", atau dalam pengertian lain "ketaatan pada agama". R. Stark dan C.Y. Glock mengartikan keberagamaan sebagai ketaatan atau komitmen pada agama yang meliputi banyak unsur seperti keanggotaan gereja, keyakinan pada doktrin-doktrin agama, etika hidup keseharian, pandangan-pandangan hidup dan lain-lain. Kelima dimensi tersebut dapat dijelaskan sebagai berikut. (Robertson, 1993: 291-297).

Dimensi keyakinan agama (ideologis). Dimensi ini memberikan pengharapanpengharapan, dimana seorang yang beragama berpengag teguh pada pendirian teologis tertentu, mengakui kebenaran-kebenaran doktrin tersebut. Salah satu hal yang esensial dalam keberagamaan seseorag adalah keyakinan terhadap agama yang dianut secara dokmatis. Dalam hal ini adalah keyakinan yang dirumuskan dalam rukun iman.

Dimensi praktek keagamaan (ritualistik). Dimensi ini mencakup pemujaan, ketatan dan hal-hal yang dilakukan orang untuk menunjukkan komitmen terhadap agama yang dianutnya. Indikasinya merujuk pada pengamalan syariat Islam yaitu pengamalan ibadah-ibadah khusus seperti shalat, puasa, zakat, haji, dan lain-lain. Praktik-praktik keagamaan ini mencakup dua hal yaitu pertama, ritual yang mengacu pada seperangkat ritus seperti tindakan keagamaan formal dan praktik-praktik suci. Kedua, ketaatan, berbeda dengan aspek ritual yang khas publik dan formal. Ketaatan mengacu kepada hal yang sangat personal- individual. Pengertian ini diarahkan pada amal-amal seperti shalat sunnah dan membaca al qur'an.

Dimensi pengetahuan agama (intlektual). Dimensi ini mengacu pada harapan bahwa orang-orang yang beragama setidaknya mengetahui sejumlah minimal pengetahuan mengenai dasar-dasar keyakinan ritus-ritus. Kitab-kitab suci, dan tradisi-tradisi. Dimensi ini menggambarkan sejauh mana seseorang mengetahui tentang agamanya. Yaitu sejauhmana aktivitas seseorang dalam menambah pengatahuan keagamaannya, misalnya apakah ia mengikuti pengajian, membaca buku-buku agama, dan mengkaji tafsir al quran.

Dimensi penghayatan keagamaan (eksperensial). Dimensi ini menitik beratkan pada penghayatan mengenai pengalaman keberagamaan seseorang.Dimensi pengakaman agama (konsekuensial). Dimensi ini mengacu pada identifikasi pada keyakinan keagamaan, praktik, pengalaman, dan pengathuan-pengetahuan seseorang dari hari ke hari. Dimensi ini menerangkan tingkat sejauhmana seseorang konsekwen dengan ajaran agamanya, seperti mampukahia menjauhi larangan-larangan agama seperti larangan, berjudi, berzina, mabuk-mabukkan, atau meyalahkan obat-obat terlarang. 


\section{Pondok Pesantren Sepuh Masjid Agung Payaman Magelang}

Pondok Sepuh ini terletak di Dusun Kauman Desa Payaman Kecamatan Secang Kabupaten Magelang Propinsi Jawa Tengah, tepatnya terletak di Jln. Raya Payaman Magelang. Pondok ini berdiri sejak tahun 1957 dengan nama "Pondok Sepuh" karena yang menjadi santri adalah orang-orang jompo. Pondok ini didirikan oleh KH. Muhammad Siradj, beliau digambarkan sebagai seorang yang terbuka dan moderat, sehingga siapapun juga dapat menjalin hubungan dengan beliau, walaupun latar belakang berbeda dan sepanjang tidak merugikan umat Islam dan masyarakat. Hal ini di mungkinkan karena beliau di anggap sebagai ulama' atau "waliyyulloh" yang sudah mencapai maqom tinggi.

Awal kehidupan KH. Muhammad Siradj banyak diisi dengan mencari ilmu diberbagai daerah dan negara. Dengan melihat kondisi masyarakat saat itu yang jauh dari ajaran-ajaran agama Islam, KH. Muhammad Siradj mulai berdakwah dengan mengadakan pengajian keliling dengan berisi nasihat keagamaan. KH. Muhammad Siradj menggunakan mediasi budaya sebagai sarana dakwahnya. Semenjak saat itu, banyak orang-orang yang mayoritas lanjut usia berdatangan ke masjid untuk "tabarukan" (mengharap barokah) dari KH. Muhamad Siradj sehingga, tidak sedikit dari mereka itu tidur di masjid. Semakin lama semakin banyak orang lanjut usia berdatangan kemudian di bangunlah pondok pesantren sepuh tersebut.

KH. Muhammad Siradj wafat pada tahun 1959 kemudian digantikan oleh putranya yaitu KH. Ghozin sampai tahun 1975. Setelah KH. Ghozin wafat digantikan oleh putranya yaitu KH. Syakir Ghozin. Semasa kepemimpinan KH. Syakir Ghozin inilah pondok sepuh mengalami perkembangan dan modifikasi model pembelajaran. KH. Syakir Ghozin wafat pada tahun 2006, kemudian pondok sepuh dikelola secara tim sampai saat ini.

Hingga saat ini pondok pesantren Sepuh dihuni oleh santri lansia dari berbagai daerah. Lebih-lebih pada bulan Ramadhan banyak santri Lansia yang mengikuti kegiatan-kegiatan pengajian khusus ramadhan.

\section{Keberagamaan Santri Lansia Pondok Pesantren Sepuh Payaman Magelang}

Pesantren merupakan salah satu dari lembaga pendidikan agama yang tidak hanya berfungsi sebagai tempat transfer ilmu pengetahuan (transfer of knowlegde) khususnya ilmuilmu agama, lebih dari itu pesantren mengemban misi pembentukan karakter santri agar menjadi manusia dewasa/sempurna (insan kamil). Manusia dewasa dalam konteks ini adalah manusia beragama yang tidak sekedar mengetahui berbagai konsep dan ajaran agama (kognisi), melainkan juga meyakini, menghayati (afeksi), mengamalkan serta mengekspresikan agama (psikomotorik) dalam kehidupan sehari-hari.

Pondok Pesantren Sepuh yang berlokasi di Payaman Magelang merupakan sebuah pesantren yang secara khusus memfasilitasi dan mewadahi para pembelajar lanjut usia (lansia) yang rata-rata usianya adalah 70 tahun. Pesantren yang bertempat di komplek Masjid Payaman berada pada satu lokasi dengan makam KH Muhammad Siraj, perintis dan pendiri pondok pesantren sepuh.

Berkaitan dengan "keberagamaan", maka setidaknya keberagamaan dapat dijelaskan dalam dua perspektif yaitu; pertama agama menurut dirinya sendiri, dan kedua agama menurut pemeluknya. Agama menurut dirinya sendiri adalah agama yang bersifat objektif-normatif yang hanya dapat dipahami menurut dirinya sendiri dan tidak bisa diukur berdasarkan ukuran pemeluknya. Sedangkan agama agama menurut pemeluknya adalah sebuah kajian terhadap agama sebatas pada gejala-gejala keagamaan yang nampak pada diri pemeluknya yang kemudian diekpresikan dalam kehidupannya sehari-hari. Perilaku pemeluk agama yang mengekspresikan religiusitasnya ini kemudian disebut dengan "manusia beragama".

Terdapat banyak teori dalam kajian agama (religius studies) yang dapat digunakan untuk menguraikan dimensi-dimensi keagamaan diantaranya adalah menurut C.Y Gock \& R. Stark 
dalam American Piety: The Nature of Religios Cpmmitment (1968)yang menyebutkan lima dimensi keagamaan; beliefe dimension, ritual dimension, consequential dimension, experential dimension dan knowledge dimension. Kelima dimensi keagamaan inilah yang digunakan sebagai kerangka pikir dalam melihat perilaku keagamaan santri lansia di Pondok Pesantren Sepuh Payaman Magelang Jawa Tengah.

\section{Dimensi Keyakinan Agama (Ideologis)}

Santri lansia Payaman memiliki keragaman latar belakang yang berpengaruh pada pengetahuan mereka mengenai ajaran-ajaran agama Islam. Sehingga pengetahuan santri satu dengan yang lainnya tidaklah sama. Pengetahuan mengenai ajaran-ajaran keagamaan ini berkaitan erat dengan latarbelakang pendidikan, pekerjaan serta lingkungan mereka sebelum di pesantren.

Keimanan harus dimiliki oleh setiap orang yang beragama. Keimanan inilah yang selanjutnya menjadi dasar setiap orang untuk terus menjalankan agamanya. Secara kognitif sebagian santri sepuh pesantren Payaman ternyata tidak bisa menjelaskan sekaligus menyebutkan secara urut mengenai enam rukun iman. Walaupun sebenarnya mereka telah mengetahui akan rukun iman dan meyakininya didalam diri mereka.

Dasar-dasar keagamaan Islam sudah dipelajari dan dimiliki santri sejak kecil baik melalui keluarga maupun pengajian-pengajian. Akan tetapi karena usia dan rentang waktu yang lama - tidakbelajar - merekakesulitan untuk memberikan penjelasan mengenai rukun iman.

Keyakinan santri sepuh kepada Allah sebagai dzat tunggal yang mengatur semua makhluk, disatu sisi merupakan sebuah pemaknaan dari lafadz tahlil "laa ilaaha illallah" yang secara harfiah biasa diartikan dengan "tiada Tuhan selain Allah". Penjelasan lebih rinci mengenai lafadz tahlil ini adalah bahwasanya tiada yang berhak di sembah di bumi maupun di langit melainkan Allah semata. Dialah Tuhan yang hak dan sesembahan selain-Nya merupakan batil. Kepercayaan dan keyakinan kepada Allah adalah dasar utama dari rukun iman.

Kemudian berdasarkan ungkapan diatas diungkapkan juga mengenai keyakinan santri terhadap nabi Muhammad sebagai utusan Allah yang diyakini akan memberikan syafaat bagi umatnya. Selain itu dikatakan oleh mbah Sulasih mengenai kepercayaannya mengenai kitab suci al-Quran yang merupakan kitab yang benar-benar diturunkan dari Allah swt.

Hal senada juga diungkapkan oleh mbah $\mathrm{Hj}$. Zamrodah ketika ditanya mengenai rukun iman beliau menjawab "wis ra nyandak ngono kui" (sudah tidak sampai hal yang demikian), maksudnya adalah dia sudah tidak bisa menjelaskan lagi apa dan bagaimana rukun iman itu. Akan tetapi ketika diberitahu dan disebutkan rukun Iman tersebut, ternyata beliau masih bisa mengikuti dan melanjutkan rukun iman tersebut. Dia mengatakan sebenarnya dia sudah hafal rukun iman sebelumnya, tetapi karena sudah lama dan tidak pernah dikaji kembali hal tersebut menjadi terlupakan.

Lain dengan mbah Zamrodah, mbah Robiah (70 tahun) ternyata masih ingat dan mampu untuk menyebutkan sekaligus menerangkan dengan lengkap mengenai rukun iman walaupun dengan penjelasan yang sangat sederhana.

"rukun iman niku lek iman kepada Allah, Malaikat, Nabi, Kiamat lan Qodho Qodar, ngoten to?"(rukun iman itu pertama adalah Iman kepada Allah, Malaikatnya, Nabinya, Hari Kiamat dan Qodho Qodar, bukan begitu?)

Mbah Robiah bercerita sebenarnya sejak dahulu beliau sudah bisa mengaji dan cukup mengerti mengenai ajaran pokok dari agama Islam. Dengan belajar di pesantren Payaman dia berkeinginan untuk melancarkan mengaji dan sebagai bekal nanti ketika di Akhirat.

Iman adalah salah satu dari pokok ajaran Islam. Selain Iman masih ada dua lagi pokok ajaran Islam lain yaitu Islam dan Ihsan. Ketiga inti ajaran Islam ini yakni Iman, Islam dan Ihsan merupakan sebuah kesatuan yang harus dipahami dan dimiliki oleh setiap orang islam. 
Ketidakmampuan santri sepuh Payaman untuk mengungkapkan mengenai rukun iman tidaklah sejalan dengan keyakinan mereka terhadap Allah. Keyakinan para santri sepuh kepada Allah dan Islam semakin bertambah seiring dengan bertambahnya usia mereka ditambah dengan pengalaman berada di pesantren. "pokoke niku intine gusti Allah" (intinya adalah Allah) begitu salah satu dari petikan wawancara dengan mbah Kalimah (70 tahun) salah santri yang berasal dari Kebumen ketika ditanya mengenai keyakinan terhadap agama Islam. (Wawancara dengan mbah Kalimah, 13 September 2014)

\section{Dimensi Praktek Keagamaan (Ritualistik)}

Terkait dengan pengamalan keagamaan dalam berbagai bentuk ritual, nampak jelas pada keseharian santri sepuh Payaman Magelang. Tidak saja terbatas pada ibadah mahdhah tetapi juga ibadah ghairu mahdhah. Ibadah mahdhah berupa pengamalan syariat berupa ritual khusus seperti sholat baik wajib maupun sunnah merupakan aktifitas rutin santri sepuh. Sholat fardhu lima kali dalam sehari selalu dilakukan secara berjamaah di masjid agung Payaman. Masjid Agung Payaman merupakan pusat dari segala aktifitas kegiatan santri sepuh. Setelah shalat berjamaah kemudian dilanjutkan dengan membaca dzikir secara bersama-sama dengan dipimpin oleh imam sholat. Sholat berjamaah merupakan salah satu kegiatan yang ditekankan oleh pengasuh Pondok.

Shalat berjamaah lima waktu di masjid Payaman di pimpin langsung oleh pimpinan pesantren sepuh Kyai Tibyan yang mana rumahnya tepat berada di selatan Masjid. Setelah shalat berjamaah selesai imam bersama-sama dengan makmum membaca dzikir setelah shalat berjamaah. Setelah itu, kebanyakan dari mereka masih tetap berada di masjid untuk melakukan ibadah.

Khusus ketika maghrib hingga Isya' para santri tidak ada yang meninggalkan masjid dan tetap berada di tempat shalat mereka masing-masing. Jeda antara shalat maghrib dan isya mereka gunakan untuk i'tikaf di masjid dengan membaca berbagai dzikir secara sendiri-sendiri. Selain waktu Maghrib dan Isya', setelah dzikir sholat selesai para santri sepuh Payaman melakukan tadarus al-Quran dan dzikir-dzikir lainnya sebelum kembali ke asrama untuk beristirahat atau melakukan aktifitas yang lainnya.

Lebih khusus lagi, setelah jamaah Asyar, para santri melakukan sorogan membaca alQuran dengan sesama santri secara bergantian. Setelah kegiatan sorogan al-Quran selesai para santri membaca al-Quran masing-masing. Ada beberapa santri yang melakukan tadarus al-Quran hingga berjam-jam, ada juga yang hanya beberapa menit.

Selain sholat wajib, sholat Sunnah juga selalu santri sepuh kerjakan mulai dari shalat sunnah rawatib, tahajud, tasbih, taubat, dhuha dan lain sebagainya. Para santri sepuh yang tinggal di lingkungan masjid memang secara keseluruhan wanita. Akan tetapi para santri sepuh ini bisa melakukan setiap ritual ibadah sehari-hari didalam masjid karena mereka sudah tidak mengalami lagi masa datang bulan (haidh). Hal ini juga menjadi salah satu peraturan di pondok sepuh yang menyatakan bahwa seluruh santri yang mau masuk ke pondok sepuh merupakan wanita yang sudah tidak haidh lagi sebagaimana dituturkan oleh kyai Tibyan Pengasuh Pondok Payaman.

Khusus ketika hari Jumat setelah shalat Isya berjamaah diadakan kegiatan Quranan dan Fidaan. Setiap santri sepuh dipersilahkan memilih salah satu dari kegiatan tersebut, sesuai dengan keinginannya. Quranan yang dimaksud disini adalah kegiatan khataman al-Quran dengan bersama-sama dalam satu waktu. Model pelaksanaanya adalah dengan membagi 30 juz al-Quran dengan seluruh santri yang mengikuti Quranan.

Selain Quranan adalah fidaan. Istilah fidaan sebagaimana yang populer di antara para santri payaman ini secara umum merupakan kata lain dari dzikir fida. Secara bahasa dzikir adalah menyebut atau mengingat. Dzikir Fida yang menjadi rutinitas mingguan santri sepuh payaman merupakan salah satu cara santri untuk mengingat Allah. Dzikir fida' juga disebut 
dengan dzikir penebusan, yaitu menebus kemerdekaan diri sendiri atau orang lain dari siksaan Allah swt dengan membaca lafadz laa ilaaha illallah atau surat al-ikhlas dengan hitungan tertentu.

Selain Quranan dan fidaan ada lagi kegiatan rutin yang dilakukan para santri sepuh selama di pesantren, para santri sepuh menyebutnya dengan "berjanjen". Kegiatan "berjanjen" dilakukan setiap malam rabu oleh seluruh santri. Berjanjen merupakan sebuah istilah yang biasa digunakan oleh para santri sepuh untuk menyebut al-barzanji. Istilah Quranan, fidaan dan juga berjanjen merupakan sebuah penyederhanaan istilah sekaligus bentuk penyesuaian istilah Arab dengan lisan orang Jawa. Quranan untuk khataman al-Quran, fidaan untuk dzikir fida dan berjanjen untuk albarzanji.

\section{Dimensi Pengetahuan Agama (Intelektual)}

Para santri sepuh kebanyakan hanya mengikuti pengajian yang diadakan di lingkungan pondok. Kegiatan pengajian yang ada di pesantren ini diadakan setiap hari secara rutin, dari pagi jam setengah tiga pagi hingga sore hari habis asyar. Kajian ilmu yang diikuti oleh para santri beragam mulai dari tafsir al-Quran, fiqih, tauhid, akhlak dan lain sebagainya.

Pelaksanaan kajian agama di pesantren Payaman bertujuan untuk melakukan pembinaan kepada para santri untuk lebih mendalami agama Islam terutama adalah dalam malasah tauhid dan akhlak. Lebih lanjut dengan adanya pengajian tersebut para lansia diharapkan dapat melaksanakan praktik ibadah sesuai dengan aturan yang ada. Pengajian ini dilakukan setiap hari dengan tenaga pengajar yang berbeda-beda.

Usia dan keadaan fisik para santri sepuh yang sudah lemah ditambah dengan banyaknya kegiatan pesantren membuat mereka tidak bisa lagi mengikuti kegiatan keagamaan yang ada di luar pesantren. Sebagaimana tuturan dari mbah Robiah berikut "Bendinten wonten pengaosan tetapi njeh gak pernah ngaji ditempat lain, hanya disini saja." (setiap hari-diPesantren Sepuh Payaman — adakajian keagamaan, tetapi saya tidak pernah mengikuti pengajian di tempat lain, hanya disini saja).

Selain pada kajian tafsir al-Ibriz, para santri sepuh tidak ada yang membawa dan mempunyai kitab yang sedang dikaji oleh ustadz. Lebih jauh lagi ternyata para santri tidak mengetahui kitab apa yang dibaca oleh ustadz dalam kajian tersebut. Setiap pengajian mereka hanya dianjurkan oleh kyai untuk datang dan mendengarkan pengajian tersebut. Para santri sepuh payaman biasa mengistilahkan kajian-kajian di pesantren dengan "nguping". Istilah nguping sendiri merupakan istilah bahasa jawa yang berasal dari kata kuping yang berarti telinga. Istilah nguping secara sederhana bisa diartikan dengan mendengarkan dengan seksama.

Memang dalam forum pengajian di pesantren sepuh Payaman bisa dikatakan bahwa kebanyakan santri hanya datang dan mendengarkan ceramah dari ustadz yang berada didepan para santri. Tetapi walaupun hanya sebagian kecil, masih ada santri sepuh yang membawa buku catatan ketika mengaji. Mereka mencatat bagian-bagian penting dari pengajian yang mereka tangkap dari ustadz.

Satu-satunya kitab yang dimiliki dan dikaji oleh para santri sepuh Payaman adalah kitab tafsir al-Ibriz karya KH. Bisri Mustofa. Kitab al-ibriz merupakan sebuah kitab tafsir yang menggunakan bahasa Jawa sebagai pengantarnya.Pemilihan kitab al-ibriz di pesantren Payaman untuk kajian tafsir al-Quran merupakan pemilihan yang tepat, karena santri sepuh selaku pengkaji kitab merupakan orang Jawa dan tidak tidak terlalu lancar berbahasa Indonesia. Bahasa Jawa merupakan bahasa komunikasi para santri sepuh Payaman. Kajian agama dengan menggunakan bahasa Jawa memudahkan para santri sepuh memahami isi pengajian. Tidak hanya kitab saja yang menggunakan bahasa Jawa, para ustadz pun mengajar dengan pengantar bahasa Jawa.

Tafsir al-ibriz dikaji dengan cara sorogan satu persatu kepada bu Nyai Umamah. Kajian tafsir ini hanya diajarkan kepada para santri yang sudah khatam Quran dan lancar membaca al- 
Quran. Setiap santri akan membaca tiga sampai lima baris dari tafsir al-ibriz didepan bu nyai, dan bu nyai akan mengoreksi bacaan mereka, mengartikan dan menjelaskan pengertian dari ayat dan tafsir yang dibaca para santri sepuh.

\section{Dimensi Penghayatan Keagamaan (Eksperensial)}

Kesadaran akan usia yang semakin tua dan fisik yang semakin melemah menimbulkan kesadaran tinggi akan pentingnya pengetahuan agama, kesadaran akan kematian dan kehidupan akhirat setelahnya. Kematian bisa datang kapan saja dan dimana saja, tidak ada seorang pun yang mampu mencegah dan menunda kematianya kecuali atas izin dari Allah. Kesadaran inilah yang membuat motivasi yang besar bagi para santri lansia.

Kemampuan kognitif santri lansia di pesantren Payaman sangatlah beragam. Rata-rata santri tidaklah memiliki kemampuan kognitif tentang ajaran Islam secara mendalam. Walaupun demikian keyakinan yang mereka miliki mengenai Islam beserta ajaran-ajarannya tidaklah bisa diragukan.

Pada usia yang sudah tua, para santri sepuh Payaman memiliki semangat yang tinggi untuk terus mendekatkan diri kepada Allah. Mereka meyadari bahwa hanya Allah lah satusatunya Tuhan yang menguasai seluruh alam baik dunia dan akhirat.Kesadaran yang muncul dari setiap individu santri lah yang membuat mereka memutuskan untuk mondok di pesantren sepuh Payaman. Pada usia yang sudah tua kemudian mengambil sebuah keputusan untuk meninggalkan keluarga di rumah, kenyamanan dan pelayanan anak-anak mereka untuk tinggal di Pondok merupakan bukti dan buah dari keyakinan mereka kepada kebenaran agama Allah.

Kondisi lingkungan beserta seluruh aktifitas keagamaan yang ada di pesantren di satu sisi membuat para santri sepuh mengambil sebuah keputusan yang besar di akhir usianya. Niat yang kuat untuk mencari ridha Allah serta mencari pahala yang sebanyak-banyaknya untuk bekal akhirat dalam sebuah lingkungan yang kondusif menjadikan mereka nyaman tinggal di pesantren semata-mata untuk menghamba kepada Allah.

Para santri sepuh mengatakan bahwa tinggal di pesantren sangat berbeda dengan ketika masih di rumah. Ketika di rumah sebenarnya mereka sudah melaksanakan ibadah dengan baik, tetapi kualitas dan kuantitas ibadah ketika berada di pesantren terasa lebih meningkat dan berkualitas. Menurut para santri lansia bahwa ibadah di pesantren memiliki kesan tersendiri yang menjadikan dia bersemangat dalam beribadah yang diistilahkan beliau dengan "setrum".

Sebagai orang yang sudah tua atau lanjut usia, para santri sepuh sangat sadar bahwa kehidupan akhiratlah yang menjadi tujuan. Karena keyakinannya tersebut keistiqomahan dalam beribadah di usia yang sudah tua merupakan sebuah keharusan sebagai bekal menghadapi akhirat. Keyakinan akan hal tersebut kemudian tergambar jelas dalam segala akifitas para santri sepuh ketika di pesantren baik ketika beribadah maupun dalam kehidupan sosial.

Penghayatan keagamaan yang dimiliki santri sepuh payaman dilandaskan kepada keimanan kepada Allah. Walaupun sebagian santri sepuh mengaku bahwa mereka sebenarnya tidak mengerti arti dari dzikir, ayat-ayat al-Quran, shalawat, dan juga doa yang mereka baca tetapi mereka yakin bahwa yang mereka lakukan adalah untuk kebaikan dan ditujukan kepada Allah dan Allah pasti membalasnya. "Njeh mboten ngerti, mboten ngerti, tirose pak kyai pokoke wis rasah kedowo-dowo pokoke mantab”. (ya tidak mengerti artinya, Pak Kyai mengatakan tidak usah terlalu dipikirkan yang penting yakin)".'(Wawancara dengan mbah Mudrikah, pada tanggal 14 September 2014)

\section{Dimensi Pengalaman Agama (Konsekuensial)}

Para santri sepuh meyakini bahwa segala aktifitasnya sehari-hari selalu diawasi oleh Allah dan dicatat oleh malaikat. Oleh karena itu manusia harus terus berusaha untuk selalu melakukan kebaikan di dunia. Sebagai pemeluk agama Islam, para santri sepuh berusaha untuk berpegang teguh melaksanakan perintah Allah dan menjauhi laranganya. Seseorang yang 
mampu melaksanakan perintah-perintah Allah dan menjauhi segala larangan-Nya disebut sebagai orang yang bertakwa.

Santri sepuh memahami bahwa selain harus beribadah kepada Allah dengan menjalankan sholat dan sebagainya, berbuat baik kepada sesama manusia juga harus dikerjakan, seperti menjenguk teman sesama santri yang sakit, dan silaturahim ke rumah santri yang lain. Diakhir kata beliau mengatakan bahwa manusia memiliki malaikat masing-masing yang terus mengawasi dan mencatat amal.

Kondisi fisik yang sudah menurun adalah hal yang tidak bisa dihindari oleh semua orang lansia, begitu juga dengan para santri sepuh di Payaman. Masalah kesehatan merupakan salah satu masalah utama yang dihadapi para santri di pesantren sepuh ini. Ketika ada santri sepuh yang sedang sakit, para santri lain secara bergantian menjeguk dan mendoakan kesembuhannya serta menghubungi salah satu anggota keluarganya untuk mengabari mengenai kondisi santri yang sedang sakit.

Hubungan santri dengan santri yang lain selama di pesantren terlihat sangat akrab. Berdasarkan pengamatan dari penulis para santri sepuh selalu terlihat saling menyapa satu sama lain ketika bertemu, selalu berwajah yang menyenangkan dengan senyuman di bibir dan selanjutnya bersalam-salaman. Dalam istilah umum hal kegiatan ini bisa disebut dengan gerakan 3S yaitu senyum, salam dan sapa.

Senyum, salam dan sapa terjadi dengan sangat natural di pesantren sepuh Payaman. Padahal bila dilihat tidak ada sebuah tulisan apapun mengenai ajakan untuk melakukan 3S, sebagaimana yang mudah kita temukan di gedung-gedung perusahaan atau sekolahan. Mereka tidak ada bosan-bosannya untuk saling bertegur sapa satu sama lain walaupun mereka bertemu setiap hari dan juga tinggal di dalam sebuah lingkungan yang sama.

Sudah menjadi kewajiban bagi setiap orang Islam untuk mematuhi segala perintah Allah dan menjauhi segala laragan-Nya. Menjalankan perintah Allah dan menjauhi segala larangan dari-Nya merupakan cara untuk menjadi orang yang bertakwa. Karena sebaik-baik orang di sisi Allah adalah orang yang paling bertakwa diantara manusia. Santri sepuh Payaman di usianya saat ini mengatakan sudah banyak berubah dibandingkan masa mudanya.

Keberhasilan menghindari perbuatan maksiat banyak disyukuri oleh para santri sepuh Payaman terutama ketika mereka sudah tinggal dipesantren. Tetapi hal itu tidak serta merta bisa dilakukan secara instan, perlu proses yang membutuhkan waktu yang cukup untuk menghindari segala bentuk kemaksiatan. Di satu sisi diakui bahwa pesantren merupakan sebuah tempat yang ideal dan kondusif untuk melatih diri menjadi seorang hamba Allah yang bertakwa.

\section{Kesimpulan}

Simpulan yang dapat dipaparkan dalam artikel ini adalah pertama,dimensi keyakinan agama (ideologis) pada santri Lansia payaman mewujud dalam keyakinan terhadap rukun iman berupa kepasrahan penuh terhadap Allah sebagai dzat tunggal yang mengatur semua makhluk yang manunggal pada lafadz tahlil "laa ilaaha illallah", keyakinan akan dipantauanya semua perilaku manusia oleh para malaikat yang ditugaskan oleh Allah, Keimanan kepada nabi Muhammad nabi akhir zaman yang dapat memberikan syafaat bagi umatnya, kitab-kitab Allah, hari akhir/ kiamat, dan ketentuan, kepastian (qodho-qodar) Allah. Pada umumnya para santri sepuh Payaman tidak mampu mengungkap secara verbal dimensi keyakinan yang dirasakan. Keyakinan para santri sepuh kepada Allah dan Islam semakin bertambah seiring dengan bertambahnya usia mereka ditambah dengan pengalaman berada di pesantren.

Kedua,Dimensi Praktek Keagamaan (Ritualistik) pada Santri lansia Payaman mewujud dalam praktik kegiatan keagamaan baik mahdloh sepeti shalat, puasa, zakat, dan ghairu mahdlah seperti zikir, fida', tadarus al-Quran, puasa sunnah, seperti Senin-Kamis, puasa 13,14,15 pada tiap bulan, puasa Asyura, puasa Nifsu Sya'ban, puasa Rajab satu bulan dan lainnya. Selain itu ada beberapa santri yang yang telah bergabung dalam thariqah 
tertentu.Ketiga, dimensi Pengetahuan Agama (Intelektual) pada santri lansia Payaman mewujud dalam aktifitas pembelajaran dan kajian santri dengan menggunakan kitab al-Ibriz-judul lengkapnya al-ibriz li Ma'rifah Tafsir al-Quran al-Aziz karya KH. Bisri Mustofa. Metode yang digunakan dalam pembelajaran dengan metode "nguping" yaitu metode denganmendengarkan dengan seksama. Berbagai aktifitas yang dilakukan oleh para santri lansia dalam keaykinannya dijadikan sebagai bekal di akhirat.

Keempat, dimensi Penghayatan Keagamaan (Eksperensial) mewujud dalam Keyakinan dan kesadaran bahwa sangat sadar bahwa kehidupan akhiratlah yang menjadi tujuan. Karena keyakinannya tersebut keistiqomahan dalam beribadah di usia yang sudah tua merupakan sebuah keharusan sebagai bekal menghadapi akhirat. Kelima, dimensi pengalaman agama (konsekuensial) mewujud dalam keyakinan para santri lansia bahwa segala aktifitasnya seharihari selalu diawasi oleh Allah dan dicatat oleh malaikat. Oleh karena itu manusia harus terus berusaha untuk selalu melakukan kebaikan di dunia. Kondisi fisik yang sudah melemah menyebabkan santri sepuh di Payaman mengalami berbagai masalah seperti kesehatan, dan daya tahan. Pengalaman-pengalam hidup sewaktu muda menjadi dasar untuk terus beramal, belajar dan beribadah menuju keridaan Allah.

\section{Daftar Pustaka}

Agus, Salim. (2006). Teori dan Paradigma Penelitian Sosial, Yogyakarta: Tiara Wacana

Baharuddin.(2009). Pendidikan dan Psikologi Perkembangan, Yogyakarta: Ar-Ruzz

Bandiyah, Siti. (2009). Lanjut Usia dan Keperawatan Geronotik. Yogyakarta: Muha Medika.

Departemen Agama RI.Al-Qur'an Terjemah. Bandung: PT. Sygma Examrdia

Hurlock. Elisabeth B. (2002). Psikologi Perkembangan:Suatu Pendekatan Sepanjang Rentang Kehidupan. Jakarta: Erlangga.

Husna,Na'ilatul. (2009). Pembinaan Agama Islam Terhadap Lansia di Panti Sosial Tresna Werdha Budi Luhur Kasongan Bantul. Fakultas Tarbiyah STIQ

Jalaluddin. (2007). Psikologi Agama: Memahami Perilaku Keagamaan dengan Mengaplikasikan Prinsip-prinsip Psikologi, Jakarta: Raja Grafindo

Leahay, Louis.(1996). Misteri Kematian Suatu Pendekatan Filosofis, Jakarta: Gramedia Pustaka Utama

Leahay, Louis. (1996). Misteri Kematian Suatu Pendekatan Filosofis, Jakarta: Gramedia Pustaka Utama

Machali, Imam \& Nur Sufi Hidayati, Pendidikan Agama Islam pada Santri Lanjut Usia di Pondok Pesantren Sepuh Masjid Agung Payaman Magelang. An Nur Jurnal Studi Islam Vol VI Nomor 1 Juni 2014. [41-59].

Mappiare,Andi. (1993).Psikologi Orang Dewasa,Surabaya: Usaha Nasional Media

Miles, M.B, dan Haberman, A.M,. (1994). An expended sourcebook; qualitative data analysis, $J, .\left(2^{\text {nd }}\right.$ ed), London, Sage Publications

Moleong, Lexy J. (1996).Metodologi Penelitian Kualitatif, Bandung, PT Remaja Rosdakarya 
Unisia, Vol. XXXVI, No. 81 Juli 2014

Robertson, Roland. Ed. (1993).Agama: dalam Analisa dan Interpretasi Sosiologis, Jakarta: Grafindo Persada

Sopiatin, Popi. (2011).Psikologi Belajar dalam Perspektif Islam, Bogor: Ghalia Indonesia

Suardiman, Siti Partini. (2011). Psikologi Lanjut Usia. Yogyakarta: Gajah Mada University Press

Sugiono, (2011). Metode Penelitian Pendidikan:Pendekatan kuantitatif, kualitatif dan R\&D, Bandung, Alfabeta

Syah, Muhibbin. (2009).Pskologi Belajar. Jakarta: Rajawali Pers

Wawancara dengan mbah Kalimah, 13 September 2014.

Wawancara dengan mbah Mudrikah, pada tanggal 14 September 2014 